\title{
Global Hijriyah Calendar as Challenges Fikih Astronomy
}

\author{
Maskufa \\ Syarif Hidayatullah \\ State Islamic University Jakarta, Indonesia \\ maskufa@uinjkt.ac.id
}

\begin{abstract}
Unification of hijri calendar occupies very important position because the calendar system adopted as symbol of civilization, particularly for Islamic civilization which no enter the era of 1.5 millennium and has not global calendar system. The hijri calendar system is lunar calendar based on the circulation of the moon around the earth. In astronomical science, the movement of the moon from new month to the next can be calculated carefully and accurately so that the demands of the predictable calendar system can be fulfilled. The discourse of the hijri calendar in the Islamic world is closely related to the use of method in determining the beginning of the lunar month. Todays, there are two methods used by Muslims in determining the beginning of the month, the method of Hisab and Rukyat. The method of hisab is predictable and its accordance with the calendar is also predictable, while the rukyat method is nonpredictable, bringing the correlation between two methods that challenge astronomical jurisprudence. This is because the Hijri calendar does not only serve the accuracy of administrative affairs but also establish the timeliness of the worshiping time.
\end{abstract}

\section{Keywords-Global Hijriyah Calender; Fikih Astronomy;}

\section{INTRODUCTION}

Moslems are still missing for the presence of the global hijri calendar since some ritual religious activities such as Ramadan fast, Idul Fitri and Eid al-Adha, pilgrimage, zakat fitrah, zakat mal are related to the time. The organization of those times for Muslims around the world have no certainty yet in the present era, while the certainty of that time becomes very important. The organization of time will make easier for policy makers in determining religious holidays, the certainty of applying for leave periods for workers especially those living in Muslim minority countries, and certainty of time in performing religious rituals.

Calendar as system of organizing time consists of unit of days, weeks and years require the certainty of time units made predictable, accurate, and unificated. The uncertainty of this time will result in syar'i, administrative, and economic difficulties. Some example of syar' $i$ difficulties are Ramadan fasting, Idul Fitri, Zakat fitrah, Eid al-Adha, wukuf, and sacrifice. While some administrative difficulties are time markers in the mailing, schedule of activities in various agencies and others, and economic difficulties are business transactions in both the real and the stock markets.

Religious holidays including Idul Fitri are one part of the event and market anomaly effect that occur in the capital market. Idul Fitri holiday in calendar contains holiday effect; stock income during holiday is much higher than usual days (Julia Utomo and Herlambang, 2011: 378). On the stock exchange market, Idul Fitri holiday is an action of market participants to sell shares before the holiday and buy it back after the holiday (Hinawati, 2016: 37). These difficulties can only be answered by the certainty of the time set out in the calendar accurately, completely, and relevantly that necessary for decision makers in determining holidays and leave together. It is also necessary for market participants to spend their money and investors in turning their business. The difficulty of planning due to uncertainty in the Islamic calendar was delivered by one of the representatives of Muslims from Europe on "Program of Preparatory Meeting for International Crescent Observation" held in Istanbul on 18-19 February 2013 (Susiknan, 2013). According to him: "we in Europe live in an order and orderly environment therefore we really hope Muslims have an orderly calendar so there is no difference in determining the beginning of Ramadan, Shawwal, and Zulhijjah" he said.

The universal time of valid information in the hijri calendar is not available yet. Each country and religious organization makes its own hijri calendar with different criteria. As a result, holidays are set on different days in 2 or 3 days. In Indonesia, in 2008 the determination of Idul Fitri holidays predicted that there would be no differentiation. However in reality the differentiation till 5 days. Likewise in 2011, the differentiation could not be avoided. It gives an unfavorable impression, ie Muslims are not united in celebrating their Lebaran. Compared with the Christian calendar, the information of the religious holidays for Christians has been presented with certainty and accuracy so that they can celebrate simultaneously around the world.

Beside being time of organizing system, calender is also a system of civilization. The existence of the calendar as "civilizational imperative" firmed by Syamsul Anwar (2014: 243) quotes Al-Alwani. Ironically for 1500 years ( 1.5 century) 
Islamic civilization did not have accurate and united time. The existing Hijri calendar is still local with variety of criterias that result in differentiation in unavoidable certain moments. As a result Muslims pragmatically use the Gregorian Calendar. The consequences of the use of Gregorian calendar in business operations for Muslims resulted 11.5 days per year, in the span of 30 years, the zakat for a year does not paid. The accumulated zakat by Tono Saksono $(2015,83)$ will continue. The debt of this civilization must be answered immediately with the presence of united hijri calendar that accurate and well-tested in both syar'i and astronomical sciences with the principle of one day one date around the world.

It shows that the organizing of time which is the primary function of the calendar occupied an important position for human life in social and economic activity. Moreover Islam adds the importance of the presence of calendars with the exercise of worshipping. Therefore, the presence of calendar for Muslims become very important. With technology and human science, careful and accurate calculation of time in the calendar system using particular astronomical cycle (lunar system) can be done. The synergy between technology, science and religious understanding as well as the contextualization of religious teachings on the time of worship should also be done.

\section{HiJRIyAH GLOBAL CALENDAR MODEL OF TURKISH CONGRESS AND MABIMS 2016}

The unification of the global Islamic calendar is not as easy as the union of the Christian calendar based on the sun's circulation with its fixed date border line in the Pacific Ocean. Hijri calendar based on monthly circulation calculated every month between 29 or 30 days resulted in changing date line in each month. Consequently, the moon's visibility is not fixed in one place to determine beginning of month, but it changes in place around the world. Nevertheless, the effort to realize global Islamic calendar still continue. Until now, there are three thoughts about the global Islamic calendar with single zone (base) or known as the unification calendar, which is the calendar initiated by Jamaluddin Abdul Raziq. The category based on two zones are the Qosum calendar, Audah calendar and al-Qudhah Calendar, while the Calendar based on the three zones is Muhammad Ilyas calendar.

In unification calendar, Jamaluddin Abdul Razik (2004: 78-83) prefers conjunction before 12:00 universal time without considering the chance of rukyat or forming of the moon and the sunset. Dual calendar zones Nidal Qosum (2000: 1), Sharaf al-Qudat, and Mohammad Syaokat Mohammad Audah (2001: 5) divide the earth in two zones namely the western zone (the American continent) and the eastern zone (other than America). If Nidal Qosum uses the criteria of ijtimak, Mohammad Audah uses imkân al-ru'yat, and Sharaf al-Qudat uses rukyat criteria. The calendar of Muhammad Ilyas (1997: 69) divides the earth into three zones, the eastern zone (Asia, the Pacific and Australia), the central zone (Asia, Europe and Africa), and the western zone (all of America), according to the universal Islamic calendar can only be made using the concept of imkân al-ru'yat (NH Khan and Akmal, 2001: 1).

The division of the world territory in some zones has not given solution for the global hijrah calendar, so in 2016 there were two historic events held in the search for common ground and effort to unify the global Islamic calendar. First, the International Congress on the Unification of Hijri Calendar from 28 to 30 May 2016 in Istanbul Turkey. Second, Muzakarah Rukyat and Taqwim Islam Member State of MABIMS was held in Baitul Hilal Port Dickson Negeri Sembilan Malaysia.

The International Congress of Hijri Unity Calendar took place in Turkey from 28 to 30 May 2016 was confronted with two choices: the use of zonal calendar that divides the world into two zones ie the western zone and the eastern zone or the unification calendar that one day one date for the whole world as well as the Christian calendar. After voting process between bizonal calendar or unification calendar (Anwar, 2016)the Congress finally chose the united calendar.

The results of the Turkish congress of 2016 actually reinforce the criteria that have been stated by the Congress of the Early Determination of the Kamariah Month in Istanbul in 1978, which set parameters with hilal height at least $5^{\circ}$, minimum elongation of $8^{\circ}$ and global matlak (MoRA, 2007,45). Nevertheless, the 1978 congress was still the basic rukyat in determining the beginning of the lunar month, while at the congress in 2016 the parameters of hisab is used and leaved the rukyat.

The criteria of the global Hijri calendar (Anwar, 2016: 2324) received by the participants of the Turkish Congress session of 2016 are: (1) the world is considered a unity, the new moon begins simultaneously throughout the region; (2) the new moon begins when in any part of the earth before 24.00 GMT met the criteria: elongation of $8^{\circ}$ or more and the height of the hilal above the horizon at sunset at least $5^{\circ} .3$. The calendar correction is performed when the above criterias are met after midnight, then the new month is set with the following conditions: a. If imkân al-ru'yat as the 1978 Turkish Congress criterion has occurred somewhere in the world and ijtimak in New Zealand occurred before dawn. b. Imkân alru'yat mentioned in point (a) occurs in the continent of the America. Hisab used as determinant of the entry of new moon in this unification calendar is hisab imkân al-ru'yat.

The second event is related to the effort to find common ground in determining the beginning of regional lunar month of Muzakarah Rukyat and Takwim Islam Member State MABIMS held on 2-4 August 2016 at Baitul Hilal Complex Port Dickson Negeri Sembilan Malaysia. The result of Muzakarah was to change the old criterion (2:3:8) to the new criteria of hilal height $3^{\circ}$ and elongation of $6.4^{\circ}$ (Djamaluddin, 2016). The new criteria of MABIMS or the term Susiknan Azhari proposed (2016): Neo Visibility Hilal MABIMS, is scientifically astronomical argumentation and according to Thomas Djamaluddin it is derived from compilation of international hilal testimony that the height of the sun-moon at sunset to observe is $4^{\circ}$. Since the sun's high at sunset is $-0^{\circ} 50^{\prime}$, the minimum monthly height is $4^{\circ}-0^{\circ}$ $50^{\prime}=3^{\circ} 10$ 'and to facilitate the count the minimum height of 
the hilal calculated from the center of the moon and rounded to $3^{\circ}$. This data is obtained from the results of Ilyas (1988) and Caldwel and Laney (2001). The minimum elongation month of $6.4^{\circ}$ was obtained from Odeh's research (2006).

Conceptually the result of the Turkish Congress 2016 and Muzakarah MABIMS 2016 open opportunities for the realization of the global hijri calendar because of the possibility of visibility moon with criteria imkân al-ru'yat highly accurate enough. In the shar'i perspective, it is necessary to have global hijri calender so that fasting, zakat fitrah, and sacrificial worship can be done at the appointed time.

\section{GlobAl CALENDAR IMPLEMENTATION ON TURKEY MODEL AND MABIMS IN ASTRONOMY JURISPRUDENCE}

The hijri calendar determined by the motion of the moon (lunar system) had function to determine the precision of the first month of the kamariyah. Some of early months of the kamariyah are related to the implementation of worshipping in Ramadan, Shawwal, and Zulhijjah. Aspects of shar'i and science in these three months became the domain of astronomy figh. Belowis the criterion of the resulted Turkish congress with the position of the new moon in the entire world.

Table 1. Position of Early Hilal on Syawal Moon $1437 \mathrm{H} \& 1438 \mathrm{H} *$

\begin{tabular}{|c|c|c|c|}
\hline \multirow{2}{*}{$\begin{array}{c}\mathrm{Nu} \\
\text { mber }\end{array}$} & \multirow[t]{2}{*}{ City } & \multicolumn{2}{|c|}{ Hilal Position } \\
\hline & & $1437 / 2016$ & $1438 / 2017$ \\
\hline 1. & Jakarta & $-1.0^{\circ}$ & $3.56^{\circ}$ \\
\hline 2. & Canberra & $-0.3^{\circ}$ & $3.5^{\circ}$ \\
\hline 3. & Mecca & $-0.7^{\circ}$ & $4.7^{\circ}$ \\
\hline 4. & Istanbul & $-0.2^{\circ}$ & $2.4^{\circ}$ \\
\hline 5. & Kairo & $-1.1^{\circ}$ & $3.9^{\circ}$ \\
\hline 6. & Rabat & $-0.4^{\circ}$ & $4.5^{\circ}$ \\
\hline 7. & Madrid & $-1.2^{\circ}$ & $3.3^{\circ}$ \\
\hline 8. & Rio de Janeiro & $5.3^{\circ}$ & $10.2^{\circ}$ \\
\hline 9. & Lima & $6^{\circ}$ & $11.6^{\circ}$ \\
\hline 10. & Washington & $1.2^{\circ}$ & $5.7^{\circ}$ \\
\hline 11. & Los Angeles & $2.5^{\circ}$ & $7.9^{\circ}$ \\
\hline 12. & Houston & $2.6^{\circ}$ & $8.1^{\circ}$ \\
\hline
\end{tabular}

Table 1, shows the criteria of the Turkish Congress 2016 in practice can not be applied for the whole year. There were only certain years where the position of the new moon throughout the region showed wujûd al-hilâl. In the determination of Shawwal $1437 \mathrm{H}$, indicates that for the American region (western) hilal already existed on $5^{\circ}$, while other regions (East region) the new moon as a marker of the new moon has not existed. Eventhough the whole area is considered as jurisdiction, the eastern region has not entered the new moon. This will affect the implementation of the worship done on the right time. Whereas the valid condition of fasting, zakat fitrah, and Qurban done at the appointed time. See the following hilal maps:

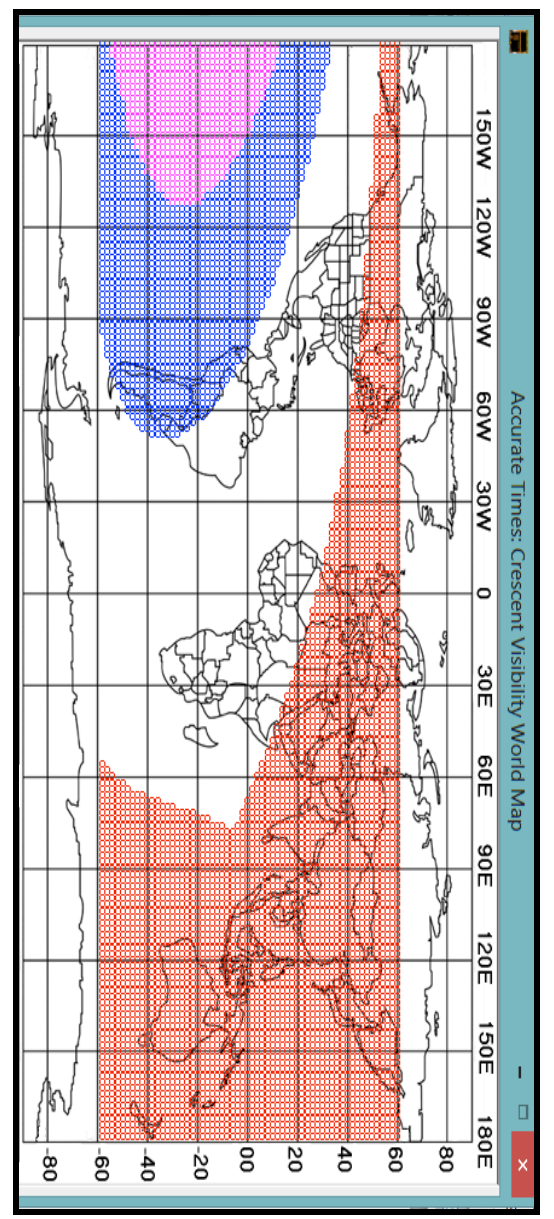

Fig. 1. Map of Hilal Visibility on Early Syawal 1437H/2016M (Odeh)

The map of early hilal visibility on Shawwal $1437 \mathrm{H} /$ 2016M above shows that countries in Asia, Europe, Middle East, part of Africa, North America and South America are in the red shade, ie the position of the moon has already set earlier from the sunset (hilal not existed). Some parts of southern Africa, North and South America are in colorless shading, which are not possible to be rukyat. Few areas of South America such as Brazil and Peru are likely to see the hilal even with optical aids.

The case of the early determination on Shawwal $1437 \mathrm{H} /$ 2016 showed that the criteria of imkân al-ru'yat $5^{\circ}$ on Turkish congress 2016 occured anywhere without any territorial limitation apparently leave the legal problem in doubting of doing worship in the wrong time. The $5^{\circ}$ hilal position in Syawal $1437 \mathrm{H}$ case in Brazil and Peru (western region) can not be applied to all regions of the world since the eastern part of the hilal is not yet existed. Therefore, it is necessary for markaz visibility of crescent moon to reach the visibility of the new moon for wider area, and more precisely the markaz 
located in the eastern region such as Indonesia. This is because the movement of the moon around the earth so that the zero degrees line separated the area has or not wujûd al-hilâl can shift in every month. For comparison with the moon visibility map of Syawal $1437 \mathrm{H} / 2016 \mathrm{M}$ above, see the moon visibility map of Syawal $1438 \mathrm{H} / 2017 \mathrm{M}$ :

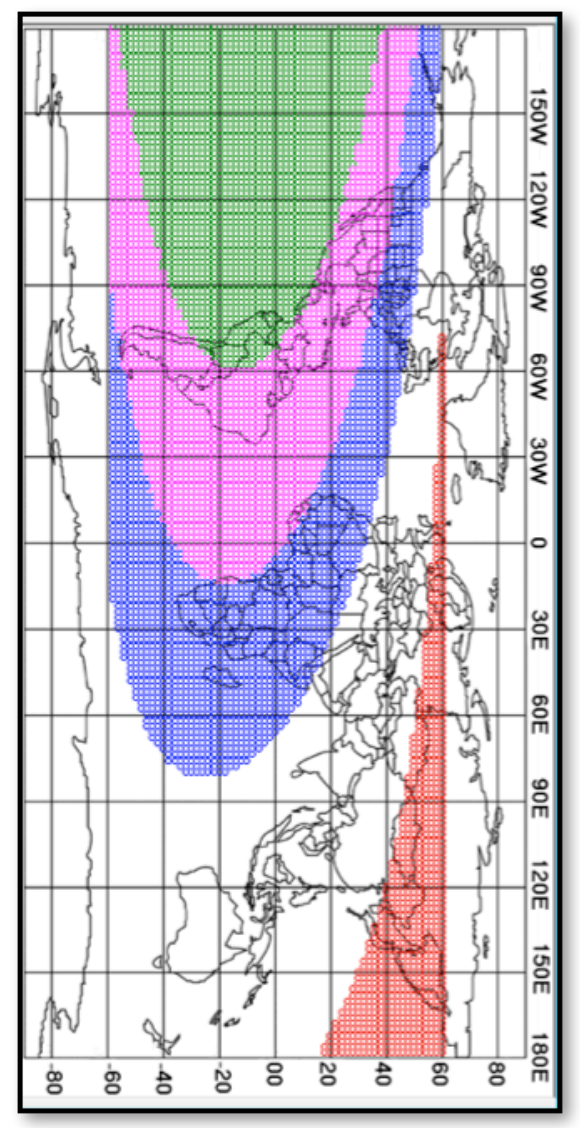

Fig. 2. Map of Hilal Visibility on Early Syawal 1438H/2017M (Odeh)

The map visibility of hilal on Syawal 1438H / 2017M above describes that the hilal position in most of the region is in the wujûd al-hilâl state with range of $2^{\circ}$ to $11^{\circ}$ so that the beginning of Shawwal 1438 can be held simultaneously on August 23, 2017.

The Indonesian Goverment through the Ministry of Religious Affairs welcomed the result of the 2016 Turkish Congress and Muzakarah MABIMS 2016 by initiating Hisab Rukyat Team Meeting of the Ministry of Religious Affairs of Indonesia on October 4, 2016. Minister of Religious Affairs Lukman Hakim in his speech stated that common view needs to be built in order to unify the Islamic calendar. The government plays as facilitator to discuss the aqli and naqli arguments for Maslahah. The presence of the state is needed in the effort to unify the International Islamic Calendar including in the process of bargaining about the criteria and systems to be used. If it does not involve state that has the power to communicate with other countries then the result of the meeting will not be used (Susiknan, 2016).
There are two great views of the Hisab Rukyat Team. Some acceptance of the result of Muzakarah MABIMS 2016 needed wisdom because Indonesia has unique and diversity methods and criteria in determining the beginning of the lunar month. Likewise in the manifestation of the result of the Turkish Congress needed more in-depth study because the criteria produced by the Turkish Congress still leaved problems. Others saw the result of Muzakarah as new criterion and can also be proposed to be criterion of the Global Islamic Calendar with its markaz in Indonesia. The choice of Indonesian territory as markaz will meet the Turkish criterion(Djamaluddin, 2016). On the basis of that, the hope for intersection between imkân al-ru'yat and wujûd al-hilâl will be achieved. See the example of the determining Zulhijjah $1440 \mathrm{H}$ : Data of early visibility on Zulhijjah $1440 \mathrm{H}$ from the Accurate Times program showed the hilal altitude of Indonesia as in Medan $4.5^{\circ}$, Jakarta $3.9^{\circ}$ and Biak Papua 2.9 $\circ$. Elevation of moon in Ankara Turky 5.4 degree Rabat Morocco $7^{\circ}$, and Mexico City $11.2^{\circ}$. See the following map of the following Zulhijjah 1440H / 2019M hilal visibility:

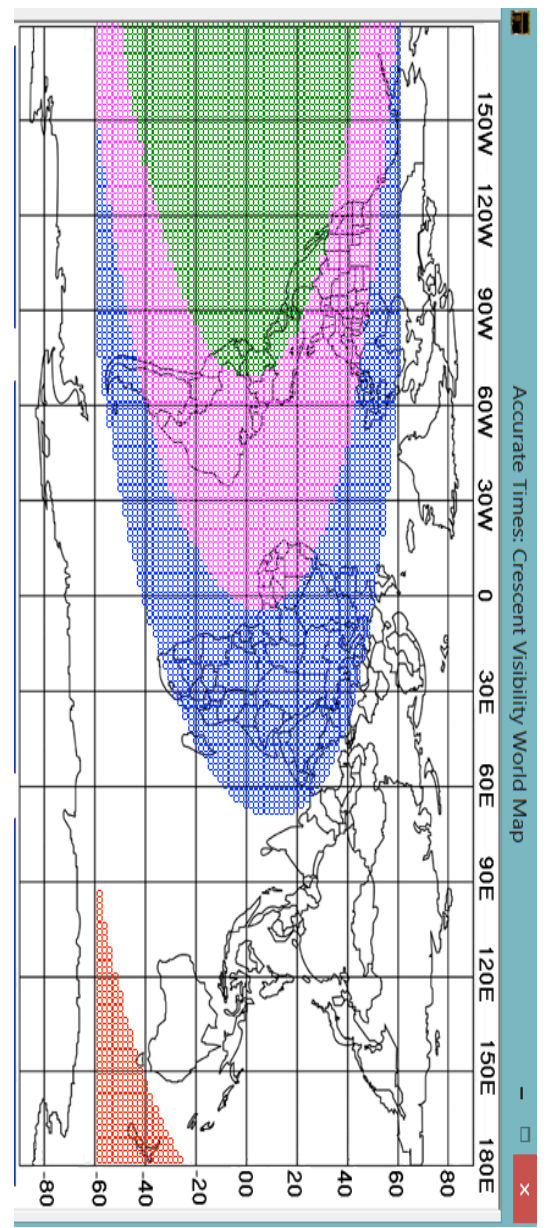

Fig. 3. Map of Hilal Visibility on Early Syawal 1440 H All Over The World

From the visibility map of Zulhijjah $1440 \mathrm{H}$ above proved that when the markaz chance of hilal visibility on $3^{\circ}$ high in Indonesia, then other areas will have higher hilal visibility opportunity. Thus, the Criteria of the Global Islamic calendar 
of Turkish congress in 2016 can also be accommodated. However, as the Minister of Religion mentioned that state involvement is necessary for an agreement on global Islamic calendar to be implemented. Thomas Djamaluddin in this course also proposed: 1) the OIC as cooperative organization of Islamic countries can be designated as global collective authority; 2) the international date line is used as the boundary of the global Islamic calendar date; and 3) the criteria of the beginning of the month at least $3^{\circ}$ height and elongation at least $6.4^{\circ}$ at sunset in Indonesian territory (Djamaluddin, 2016).

The appointment of Indonesia as markaz visibility on $3^{\circ}$ horse visa has accommodated the territory of Malaysia, Singapore and Brunei Darussalam as well asthe $5^{\circ}$ criteria of the Turkish Congress 2016 as well. However, if the visibility of the new moon $5^{\circ}$ occurs anywhere according to the result of the Turkish Congress then in the Western hilal is already existed, while in the East is not yet. The most Western territory of land is in South America and the eastern is in Western Samoa which is 20 hours different. If in South America hilal is on $5^{\circ}$ height then in Eastern region, including Southeast Asia, hilal is still under horizon.

\section{CONCLUSION}

The existence of the Global Islamic calendar becomes the hope and dream of Islamic civilization. Each civilization presents its own calendar that records event in detail. It is time for Islamic civilization to have its own calendar that has certainty and summarizes the function of doing worship and muamalat, and the only way to accept Hisab method. The effort to synergize between the achievement of science and the sacred text, between hisab and rukyat can be done with each entity to agree on the result of global decision so that the presence of global Islamic calendar becomes necessary.

\section{REFERENCES}

[1] Venny Julia Utomo dan Leo Herlambang, 2015, Effect of Lebaran Holiday for Issuers Registered in ISSI Period 2011-2013, Journal, Jestt Vol. 2 No. May 5 2015, 378.

[2] Titik Hinawati, 2016, The Effect of Idul Fitri Holiday Against Abnormal Return of Shares In Indonesia Stock Exchange, Journal Cakrawala, Vol. XI, No. 1, June 2016, 37.

[3] Azhari, Susiknan, Muktamar Turki 2013, Error! Hyperlink reference not valid., October 12, 2013.

[4] Maskufa, 2010, Determination of Islamic Holiday in Perspective of AlMuhdhor Tulungagung Community, Report of Research, Lembaga Penelitian, Jakarta.

[5] Fathurohman, Oman, Some Countries That Predicted Sawwal August 30, http://wwW.muhammadiyah.or.id, September 30, 2011.

[6] Anwar, Syamsul, 2014, Discussion and Correspondence of the Global Hijri Calendar, Suara Muhammadiyah, Yogyakarta.

[7] Jamaluddin Abd ar-Raziq, 2004, al-Taqwîm al-Qamarî al-Islamî alMuwahad, Marsam, Rabat.
[8] Guessoum, Nidhal, Visibility of the Thin Lunar Crescent: The Sociology of an Astronomical Problem (A Case Study) http://www.icoproject.org/pdf/guessoum 2000. pdf,1, June $14,2010$.

[9] Audah, Mohammad Syaukah, Taqwîm al-Hijrî al-Islâmî, http://www.icoproject.org/pdf/2001 UHD .pdf (updated January 2007), 5, June 10, 2010.

[10] al-Qudhoh, Sharaf, Tsubût al-Shahr al-Qamarî baina al-Hadîts alNabawî wa al-'Ilm al-Hadîts, Makalah disampaikan dalam Mu'tamar al'Alamî lî itsbât al-Shuhûr al-Qamariyah 'inda 'Ulama al-Sharî'ah wa alHisâb al-Falaky held by Majma' Fiqh al-Islamî Rabithah 'Alâm alIslamy, Mekah al-Mukaromah. 32-33.

[11] Ilyas, Mohammad, 1997, Astronomy of Islamic Calendar, A.S. Noordeen, Kuala Lumpur.

[12] Khan, Muhammad N.H. dan Aamir Akmal, Justification for the use of the Universal Hejric Calendar for the Determination of Correct Islamic Dates and Reduction of Takalluf (Burden) From A Shariah Perspective, Error! Hyperlink reference not valid., 1, June 20, 2012.

[13] Anwar, Syamsul, Muhammadiyah Preceded Istanbul, http://tarjih.or.id, July 22, 2016.

[14] Dirjen Badilag MARI, Almanak Hisab Rukyat, Dirjen Badilag MARI, 3 edition, Jakarta.

[15] Anwar, Syamsul, 2016, Follow up of the 2016 Global Hijri Muslim Calendar, paper presented on National Halaqah on Hisab Expert and Fikih Muhammadiyah, MTT Majelis Tarjih dan Tajdid PP Muhammadiyah, 1437H/2016M.

[16] Azhari, Susiknan, Dialogue of the Global Islamic Calendar and Hilal Neo Visibility MABIMS, http://museum astronomi.com, December 24, 2016.

[17] Djamaluddin, Thomas, Toward Global Unity of Calendar, https://tdjamaluddin.wordpress.com, December 26, 2016.

[18] Azhari, Susiknan, The result of MABIMS Muzakarah and the Future of the Global Islamic Calendar, http://museumastronomi.com, December, 242016.

[19] Djamaluddin, Thomas, Toward New Criteria MABIMS Based on Astronomy, https://tdjamaluddin. wordpress.com, December, 242016.

[20] M. Ilyas, 1988, Limiting Altitude Separation in the New Moon's First Visibility Criterion, Astron.Astrophys.Vol.206,p.133135.http://articles.ad-sabs.Harvard.edu, December, 242016.

[21] Odeh, MSH, 2006, New Criterion for Lunar Crescent Visibility, Experimental Astronomy,Vol.18,p.39-64. http://download.springer.com/static/pdf/563, December, 24 2016.

[22] Thomas Djamaluddin, "Proposal of Academic Paper on Astronomical Early Determination Criteria of Hijriyah Month," Error! Hyperlink reference not valid., December, 242016.

[23]

[24] G. Eason, B. Noble, and I.N. Sneddon, "On certain integrals of Lipschitz-Hankel type involving products of Bessel functions," Phil. Trans. Roy. Soc. London, vol. A247, pp. 529-551, April 1955. (references)

[25] J. Clerk Maxwell, A Treatise on Electricity and Magnetism, 3rd ed., vol. 2. Oxford: Clarendon, 1892, pp.68-73.

[26] I.S. Jacobs and C.P. Bean, "Fine particles, thin films and exchange anisotropy," in Magnetism, vol. III, G.T. Rado and H. Suhl, Eds. New York: Academic, 1963, pp. 271-350.

[27] K. Elissa, "Title of paper if known," unpublished.

[28] R. Nicole, "Title of paper with only first word capitalized," J. Name Stand. Abbrev., in press.

[29] Y. Yorozu, M. Hirano, K. Oka, and Y. Tagawa, "Electron spectroscopy studies on magneto-optical media and plastic substrate interface," IEEE Transl. J. Magn. Japan, vol. 2, pp. 740-741, August 1987 [Digests 9th Annual Conf. Magnetics Japan, p. 301, 1982].

[30] M. Young, The Technical Writer's Handbook. Mill Valley, CA: University Science, 1989. 